face; face below insertion of antenne well-rounded; distance between lateral ocelii and median ocellus greater than that between one of the laterals and the eye margin; maxiliary palpi long; joints 2 and 3 subequal in length, and each as long as or longer than $\mathrm{I}$, joint 4 longer than 3 . Male.-Resembles female except in antennx, in which the funicle joints are all of equal widtb, each somewhat longer than broad, and all well separated, with rounded bases and sharply truncate tips; moderately hairy ; hairs not arranged in whorls.

Hunterellus Hookeri, n. sp.-Female - Length, 0.85 mm.; expanse, $2.04 \mathrm{~mm}$; greatest width of fore wing, $0.35 \mathrm{~mm}$. Head and mesonotum very finely shagreened, somewhat shining and furnished with many fine, short hairs. Mesopleura smooth, shining. General colour black. Antennæ dark fuscous. Front and middle tarsi and tibiæe dirty honeyyellow; hind tibise brownish in middle, honey-yellow at either end; front and middle femora light at distal end. Veins of wing dark brown.

Male.-Resembles female except in antennæ, which are lighter in colour. Described from four females and six males, reared May 22 from Rhipicephalus Texamus collected on Mexican dog at Corpus Christi, April 20, 1908.

U. S. National Museum, type No. I I,947.

\title{
PRELIMINARY REMARKS ON AMERICAN CORIZINI (HEMIPTERA).
}

BY C. F. BAKER, PARA, BRAZIL.

In Uhler's check list there appeared eleven North American species of this group, all under the genus Corizus. But one of these (hyalinus) had also been found in Europe. Two were species of Dallas, one of Say, two of Stal, and the remainder date from the monograph of the genus by Signoret, published in 1859 in the Ann. Ent. Soc., France. The descriptions of Signoret are largely drawn from colour characters, and have consequently been the cause of endless confusion and misunderstanding in the determination of the species. The colour forms are simply multitudinous "protean," as stated by Distant. In large series from all parts of North, Central and South America specimens may easily be discovered that exactly fit the descriptions of Signoret, but they are mostly mere links in vast intergrading series of forms. In collections where these forms are July, 1908 
represented by but a few specimens each, they are extremely difficult to understand. And this misunderstanding is frequently strengthened by the fact that in a single locality races are likely to be found quite pure and uniform.

The way was paved to a proper understanding of the group by Stal in the "Enumeratio," where he separated from the old genus Corizus a number of subgenera, leaving under the original name only certain old species grouped around crassicomis. These subgenera were exceedingly well founded, since in a study of many species, other co-ordinated characters may be discovered which were not used by Stal. These groups are as well founded as the generally recognized and nearly related Maccavethus, Brachycarenus and Corizomorpha, and are much more readily separable than many other genera of the Coreidæ. For my own convenience I call them "genera." Apart from other considerations, however, a careful study of these groups of Stal is the only path towards bringing order out of the utter confusion in the arrangement of the species in most American collections.

I have already before me something more than a thousand specimens of this group. Many of these specimens have previously been studied by Dr. Uhler and Mr. Heidemann. I have made a preliminary arrangement of all this material, and shall be glad now to undertake the determination of other collections, adding to such collections forms lacking to them in return for any duplicates retained.

Genus Corizus, Fall.

But one species belonging to this genus, as limited by Stal, has ever been described for North America-noveboracensis, recognized by Fitch and described by Signoret. In American collections pale forms of this are commonly referred to hyalinus, which belongs in a different genus. Novcboracensis is one of the most distinct species in the American fauna, and is represented by various forms, especially towards the West. Pallidus is a very common pale form found from Colorado to Nevada, but it agrees in all essential characters with noveboracensis, and intergrades it throughout its range. Some of the commoner forms of this species may be temporarily separated as follows : 
A. Smaller pale greenish forms; western..........pallidus, Baker. AA. Larger, darker, brownish to blackish forms.

B. Scutel yellowish, whole insect pale brown;

Nevada.................... intermedia, Baker.

BB. Scutel brown to black, body of various shades of brown, but mostly dark.

C. Length, 6-7 mm.; E. U.S. to Nevada.novaboracensis, Fh.

CC. Length, 7-9 mm.; Colo. to Nevada..occidentalis, Baker.

BBB. Scutel and most of the body above, with the legs, black...................... plutonius, Baker.

Genus Liorhyssus, Stal.

This genus has but one known American species, hyalinus, with numerous forms everywhere. In but few cases are these even geograph. ical, since the same ones constantly recur in widely-separated localities and in all sorts of combinations. Only in the extreme south have I found any clearly-marked varieties. In Cuba all the individuals taken by me are very dark, with disc of pronotum almost black. Some of these southern forms deserve distinguishing names, if South American extensions of the species have not already been named. Uhler has described one of the western forms as viridicatus.

\section{Genus Niesthrea, Stal.}

This genus contains the most highly-coloured species of the group, and is the largest genus in North America. Frequently small forms had been determined for me as ventralis and side, but both of these, together with scutatus and valialus, were originally described as about $10 \mathrm{~mm}$. in length. The large forms constitute a well-defined series, which, with a large amount of material before me, I believe to be of but specific value. The validus of Uhler varies completely into the scutatus of Stal, which is one of the most common species of the Pacific Slope. Ventralis is but sidce with lateral rows of black dots on each ventral segment. Large series collected in Nevada, Middie and Southern California and Mexico illustrate very clearly the relation between these large forms. The small forms of the genus known to me appear to belong to but three specific groups, but with many forms each; these are the lateralis of Say, the pictipes of Stal, and the side of Fabricius. Nigristernum, recognized by Fitch and described by Signoret, I believe to be the merest colour-form of lateralis. 
The typical form of lateralis is common in the Middle States, extending far to the east and far to the West, and presenting a number of conspicuous forms. Individuals more or less suffused with red may occur in almost any of the species, and especially in this. However, in the mountains of Southern California I found a uniform race of small roseatehued individuals that certainly deserve separate recognition, and I have given them the form name roseus. The luteolus of Distant appears to be but a mere variety of lateralis. The punctatus of Signoret (determined at various times for me as ventralis, which is a far larger and paler form) ranges from the North-eastern United States into Mexico and Central America, and as a general thing is remarkably uniform for one of this group. I collected a smaller paler form in Nicaragua. Structurally, punctatus is extremely close to lateralis.

The specific group, pictipes of Stal, is essentially southern, forms of the species being abundant in West Indies, Mexico, Central and South America. I have many specimens of a very uniform race from Louisiana, and doubtless it will be found eastward and westward in the Gulf States. Most abundant in Nicaragua is the form of this species named nebulosus.

Genus Arhyssus, Stal.

Stal made punciventris of Dallas the type of this group. The short antennæ, general form, and the very bristly head and thorax, are quite characteristic. After I had separated all of my material of this group, a search was made for determined punctiventris. Curiously enough, species were found in each of the other three genera which had been determined as punctiventris, but none in the gromp of which it had been made the type. Although published seven years previously, yet not one of the Dallas species is mentioned in the "Monographie du Genre Corizus." But I believe that Signoret had the true punctiventris of Dallas, and described it under the name of Bohemani. It is found throughout the United States, and occurs in most general collections of Heteroptera, though I have yet encountered no specimens properly named. Pilosus and parvicornis, both of which I have collected in the extreme south, have no good structural characters to separate them from punctizentris except size, and numerous intermediate forms occur. The borealis of Uhler had been reduced to punctiventris, but this reference is in doubt, since of various forms determined as punctiventris for me by Dr. Uhler, none are even Arhyssus. 